\title{
Peran Konselor Adiksi Dalam Menangani Korban Penyalagunaan Napza Di Pusat Rehabilitasi Narkoba Galilea Palangkaraya
}

\author{
Murdiono Simbolon ${ }^{1 *}$, Haposan Simanjuntak ${ }^{2}$, Dewi Lidya $\mathrm{S}^{3}$, Ardianto Lahagu ${ }^{4}$, \\ Zakaria Lumban $\mathrm{Gaol}^{5}$ \\ 1, 2, 3, 4, 5 Prodi PAK, STT Real Batam \\ dionpalangkaraya@gmail.com
}

\begin{abstract}
Departing from the problems seen in the lives of the adolescents that the author studied, where drug addicts are identical to the lack of attention and affection from the family, it can even be the result of association and curiosity about what drugs are. A drug addict will not recover quickly or quickly. The Galilea Foundation where the author conducted the research is a rehabilitation center that can provide information to the wider community about the dangers of drugs and information about HIV / AIDS.Therefore this paper aims to describe the dangers of drugs and to find out the function or role of an addiction counselor
\end{abstract}

Keywords: Counseling, Rehabilitation, Drugs, Abuse

\begin{abstract}
Abstrak
Berangkat dari masalah-masalah yang terlihat dalam kehidupan para remaja yang penulis teliti, dimana pecandu narkoba identik terhadap kurangnya perhatian dan kasih sayang dari keluarga bahkan bisa juga akibat dari pergaulan dan rasa ingin tahu apa itu narkoba. Seorang pecandu narkoba tidak akan dapat dipulihkan secara cepat atau singkat. Yayasan Galilea tempat penulis melakukan penelitian merupakan Pusat rehabilitasi yang dapat memberikan informasi kepada masyarakat luas tentang bahayanya narkoba serta informasi tentang HIV/AIDS. Oleh karena itu tulisan ini bertujuan untuk memaparkan bahayanya narkoba dan mengtahui fungsi atau peranan seorang konselor adiksi.

Kata kunci: Konseling, Rehabilitasi, Narkoba, Penyalahgunaan
\end{abstract}




\section{PENDAHULUAN}

Pusat rehabilitasi narkoba (PRN) Galilea yang juga institusi penerimaan Wajib lapor (IPWL) Galilea berada dibawah naungan YAYASAN GALILEA. Yayasan Galilea didirikan pada tanggal 23 Mei 2002 oleh Dodi Ramosta Sitepu beserta rekan-rekan mantan pecandu napza, yang menaruh hati untuk melayani dan memberkati kota Palangka Raya dan Provinsi Kalimantan Tengah, terkususnya pada mantan pecandu narkoba serta anak-anak jalanan untuk membina mereka kembali sehat serta berguna bagi keluarga, bangsa dan Negara. Yang menjadi Visi Yayasan Galilea ialah "Menolong Generasi Muda Indonesia Bebas Dari Narkoba Dan Memiliki Karakter Ilahi". Dan yang menjadi Misinya ialah: Hidup bebas dari keterikatan/kecanduan Narkoba, Melayani dengan Kasih, Peberdayaan melalui Pengembangan skill dan kemampuan.

Kasus pengunaan narkotikan dalam berbagai tahap pengunaan semakin tahun semakin meningkat. Berbagai upaya telah dilakukan oleh instansi terkait baik dalam program penegakan hukum, pencegahan maupun terapi dan rehabilitasi. Meningkatkan kasus ganguan penggunaan narkotika merupakan suatu penyakit yang kronis dan kambuhan dan sangat perlu waktu untuk dapat mengatasi masalah tersebut.

Pengunaan narkotika pada umumnya terjadi pada anak remaja dan berasal dari gulongan atas, sejalan dengan perkembangan masalah narkoba di Indonesia maka kelompok penggunaan makin lama terjadi pada usia yang lebih dewasa.

Ada banyak faktor yang menyebabkan seseorang pemuda dan pelajar jatuh dalam dunia narkoba. Seorang pecandu yang pemula mereka hanya ingin mencoba-coba dan merasakan kenikmatan saja, tetapi di saat seorang pecandu sudah merasakan kenikmatan narkoba itu maka pecandu itu akan ketagihan akibat dari kenikmatannya. Dampak penggunaan narkotika sangat luas dalam kehidupan individu yang meliputi dampak terhadap fisik, mental atau psikologis dan sosial. Korban penyalagunaan narkotika, psikotropika, dan zat adiktif lainnya semakin meningkat yang berdampak sangat luas terhadap perseorangan, keluarga, dan masyarakat sehingga perlu penanganan secara terpadu dan professional. Banyak korban penyalagunaan narkoba tidak dapat di pulihkan di dalam rumahsakit maupun di dalam keluarga oleh sebab itu dengan berkembangnya napza dalam dunia ini maka di buatlah yang namanya rumah TC (Therapeutic Community).

Menurut Syarifuddin Gani dalam Journalnya mengatakan bahwa Therepeutic community merupakan treatment yang menggunakan pendekatan psikososial. Dimana diantaranya adalah sesama mantan pecandu 
yang bersama-sama hidup dalam satu lingkungan untuk saling membantu dalam mencapai kesembuhan dan pemulihan. ${ }^{1}$

Bahaya narkoba hinga menjadi kecanduan tersebut memang sangat sulit untuk di pulihkan akan tetapi dengan berjalannya proses maka sipecandu tersebut akan dapat di pulihkan. Seorang pecandu narkoba tidak akan dapat dipulihkan secara cepat atau singkat karena apabila seorang pecandu sudah merasakan dan menjiwai narkoba itu dengan dalam maka seorang pecandu itu tidak akan dapat di sembuhkan akan tetapi dapat dipulihkan dengan berjalannya waktu begitu lama.

\section{METODE}

Di dalam penelitian ini, peneliti melakukan observasi (pengamatan) pertisipatif (terlibat). Peneliti sehari-harinya terlibat dalam kegiatan seharihari dengan narasumber yang akan diteliti. Disamping melakukan observasi, peneliti juga melakukan pengumpulan data dengan wawancara. Wawancara ini dilakukan oleh peneliti untuk mengetahui hal-hal yang lebih mendalam dari narasumber.

\section{HASIL DAN PEMBAHASAN \\ Pengertian Napza}

Napza adalah singkatan dari Narkotika, Psikotropika dan Zat Adiktif. Semua istilah ini, baik "Narkoba" ataupun "Napza", merujuk pada kelompok senyawa yang dapat mengakibatkan kecanduan kepada penggunanya. Senyawa-senyawa tersebut menurut pakar kesehatan adalah zat yang biasa digunakan tenaga medis kepada pasien untuk penyakit tertentu atau sebelum melakukan oprasi. Namun kini persepsi itu disalahartikan akibat pemakaian peruntunan dan dosisi yang semestinya.

Napza secara umum merupakan zat-zat kimiawi yang dapat mempengaruhi pikiran, suasanan hati perasaan bahkan perilaku yang dikonumsi dengan cara oral (simunim, dihisap dan dihisup) maupun disuntik. Hal ini dapat menimbulkan gangguan keadaan social yang ditandai dengan indikasi negative, waktu pemakaian yang panjang dan pemakaian yang berlebihan berikut beberapa pendapat ahli terhadap narkoba atau napza:

Smith Kline Dan French Clinical

Pengertian narkoba menurut para ahli yang tergabung di perusahan farmasi Smith Kline dan French Clinical di Amerika Serikat. Narkoba adalah zat-zat atau obat yang dapat menyebabkan ketidaksadaran atau pembiusan

${ }^{1}$ Yarifuddin Gani, "Therapeutic Community (TC) Pada Residen Penyalah Guna Narkoba Di Panti Social Marsudiputra Dharmapala Inderalaya Sumatera Selatan," Jurnal Konseling dan Pendidikan 1, no. 1 (2013): 54-57.55 
karena zat-zat tersebut bekerja dengan mempengaruhi susunan saraf sentral.

Menurut Warso Sasongko melihat dari UU No.22 Tahun 1997 dalam bukunya bahwa narkotika adalah zat atau obat yang berasal dari tanaman atau bukan tanaman, baik sintetis maupun Semi sintetis yang dapat menyebabkan penurunan atau perubahan kesadaran, hilangnya rasa, mengurangi sampai menghilangkan rasa nyeri, dan dapat menimbulkan ketergantungan pada setiap penggunanya.Sedangkan psikotropikaadalah zat atau obat, baik alamiah maupun sintetis bukan narkotika, yang berkhasiat psikoaktif melalui pengaruh selektif pada susunan saraf pusat yang menyebabkan perubahan khas pada aktivitas mental dan perilaku penggunanya.Dan bahan adiktif adalah zat atau bahan lain bukan narkotika dan psikotropika yang berpengaruh pada kerja otak dan dapat menimbulkan ketergantungan. ${ }^{2}$

\section{Akibat Penyalagunaan Napza}

Bagi Diri sendiri

Pemakai Napza dapat mengalami kerusakan organ tubuh dan menjadi sakit sebagai akibat langsung adanya napza dalam darah, misalnya kerusakan paru-paru, ginjal, hati, otak, jantung, usus dan sebagainya. Kerusakan jaringan pada organ tubh akan merusak fungsi organ tubuh tersebut sehingga berbagai penyakit timbul.

Pertama, Terganggunya fungsi otak dan pertumbuhan moral remaja, kedua, Intoksikasi (keracunan) yaitu gejala yang muncul disebabkan penggunaan napza dengan dosis yang dapat berpengaruh pada tubuh dan perilakunya, ketiga, Overdosis (OD) dapat berujung pada kematian karena terhentinya pernapasan (heroin) atau perdarahan otak (amfetamin, sabu) , keempat, Gejala putus zat, yaitu gejala ketika dosis yang dipakai berkurang atau dihentikan pemakaiannya, Kelima, Berulang kali kambuh, yaitu ketergantungan yang menyebabkan craving (rasa rindu pada napza) walaupun telah berhenti pakai, keenam, Gangguan prilaku atau sikap apatis, sulit mengendalikan diri, mudah tersinggung, marah, menarik diri dari pergaulan hubungan dengan keluarga dan sesama terganggu.

\section{Bagi Keluarga}

Pertama, Masalah psikologis Bila seorang anggota keluarga terkena napza, berbagai masalah akan muncul dalam keluarga itu. Mula-mula yang timbul adalah masalah psikologis, yaitu gangguan kehermonisan rumah

${ }^{2}$ Warso Sasongko, Narkoba (Yogyakarta: Istana Media, 2017).7 
tangga karena munculnya rasa malu pada diri ayah, ibu, dan saudarasaudaranya kepada tetangga dan masyarakat. ${ }^{3}$

Kedua, Masalah ekonomi atau keuangan Masalah psikologi tadi kemudian meningkat menjadi masalah ekonomi, banyak uang terbuang untuk berobat dalam jangka waktu lama. Banyak uang dan barang yang hilang karena dicuri atau dijual oleh pemakai untuk memberikan Napza.

\section{Bagi Masyarakat}

Masalah ekonomi dapat meningkatkan lagi menjadi munculnya kekerasan dalam keluarga: perkelahian, pemaksaan, penganiayaan, bahkan pembunuhan sesama anggota keluarga. Bukan hanya merugikan diri sendiri, para pemakai Napza juga bisa mengganggu masyarakat. Pemakai Napza acapkali melakukan tindakan kejahatan dan kekerasan yang merugikan orang lain. Para pemakai Napza seringkali membuat ulah, keributan dan mengganggu masyarakat. Para pemakai Napza terutama dari kalangan generasi juga tidak mungkin bisa menerima tongkat estafeta kepemimpinan bangsa, melainkan sebagaiknya jadi beban bangsa dan negara. Kejahatan tadi kemudian dapat menyebar ke tetangga, lalu masyarakat luas. Dimulai dari masalah Napza, masalah-masalah lain yang lebih luas dan berbahaya, seperti kriminalitas, prostitusi, korupsi, kolusi, nepotisme dan lain-lain dapat muncul. ${ }^{4}$

\section{Pandangan Kristen Tentang Penyalagunaan Napza}

Membahas pencegahan penyalahgunaan Napza dari sudut pandangan Kristen merupakan hal yang penting, karena dapat beberapa aspek dalam Kristen yang bersinggung dengan Napza, melalui dari aspek hukum kemudian muncul gagasan, mengapa Napza menjadi masalah yang sangat penting untuk dijawab dan dicari penyelesaiannya. ${ }^{5}$

Sebagai agama yang datang untuk membawa rahmat bagi alam semesta dan datang memperhatikan kemasalahan umum, menghindari kekacauan masa dan juga memperhatikan kesehatan, baik kesehatan jasmani maupun rohani, kristen mengambil sikap sangat peduli terhadap masalah penyalahgunaan Napza.

Didalam pandangan agama Napza adalah barang yang merusak akal

${ }^{3}$ Subagyo Partodiharjo, Kenali NARKOBA Dan Musuhi Penyalahgunaannya, 1st ed. (Jakarta: Erlangga, 2007). 33

${ }^{4}$ Lydia Harlina Martono and Satya Joewana, Menangkal Narkoba Dan Kekerasan: Belajar Hidup Bertanggung Jawab (Jakarta: Balai Pustaka, 2006). 24

${ }^{5}$ Abdul Wahid, Pelajar Indonesia Anti Narkoba Peran Pendidikan Kristen Dalam Penanggulangan Narkoba (Jakarta: Erlangga, 2016). 76 
pikiran, ingatan, hati, jiwa, mental dan kesehatan fisik. Oleh karena itu, Napza juga tergolong dalam kategori dosa.

\section{Konselor Adiksi}

Konselor rehabilitasi adalah salah satu profesi yang memiliki sikap khusus yang dibutuhkan untuk berkolaborasi dalam sebuah hubungan yang professional kepada orang-orang yang berstatus cacat untuk mencapai tujuan personal, sosial, psikologis dan vokasional tentunya diperlukan juga pengetahuan dan keterampilan didalamnya. Profesi konselor menolong individu dengan kecacatan untuk menyesuaikan diri dengan lingkungan, menolong supaya kebutuhan individu tersebut dapat terakomodasi, dan mengupayakan partisipasi penuh penyandang cacat dalam segala aspek kehidupan masyarakatarakat, terutama dalam pekerjaan.

Tujuan-tujuan konselor dalam konteks konseling merupakan pantulan dari falsafah selaku dasar-pijak tiap-tiap konselor. Sesuai dengan keragaman falsafah konselor, tuajuan-tujuan pun sangat beragam. Meskipun dalam hal ini masih di tentukan keragaman corak penamaan, namun tidak ada pertentangan prinsip sifatnya. ${ }^{6}$

Seorang pecandu narkoba identik pada kurangnya pada tanggung jawan dalam dirinya, oleh sebab itu di dalam rehabilitasi seorang pecandu anak di latih untuk lebih lagi untuk bertanggung jawan dalam perbuatan dan tingkah laku kliean pecandu narkoba.

Di dalam Yayasan Rehabilitasi narkoba Galilea, seorang konselor harus mengarahkan korban pecandu tersebut kejalan yang benar. Menajdi seorang Konselor harus bisa mengarahkan korban pecandu narkoba tersebut melewati fase-fase yang telah di buat di dalam Rehabilitasi tersebut. Di dalam Yayasan rehabilitasi Narkoba Galilea seorang konselor mengarahkan korban pecandu karkoba tersebut melewati fase-fase yang ada. contohnya, dari fase Primeri hingga pada fase Re-Entry, di dalan fese tersebut konselor harus benar-benar mengarahkan pecandu tersebut ke jalan yang benar dan memberikan solusi untuk memecahkan sebuah masalah.

Konselor Yayasan Rehabilitasi Narkona Galilea akan memberikan kepercayaan kepada korban pecandu narkoba apabila sudah melewati fase Re-Entri. Setelah korban pecandu narkoba melewati fase-fase yang di buat oleh para staff Yayasan Rehabilitasi Narkoba Galilea maka konselor akan memberikan kepercayaan yang lebih dari pada klein yang belum melewati fase-fase yang ada. re-entri akan di berikan kepercayaan malalui Henpone,

${ }^{6}$ Andi Mappiare, Pengantar Konseling Dan Psikoterapi (Jakarta: Raja Grafindo Persada, 2006). 44 
Playanan keluar dari kawasan Yayaran Rehabilitasi.

\section{Peran \& Syarat Menjadi Konselor Adiksi}

Pembahasan tentang peran konselor dalam literatur konseling kerap kali ditemukan bergandengan dengan pembahasan fungsi konselor. Bahkan, tidak jarang kedua istilah tersebut digunakan untuk menjelaskan maksud dan pengertian yang sama. Peran dikonseptualisasikan ke dalam suatu tujuan, sedangkan fungsi berarti proses. Konsep peran lebih ditekankan pada suatu bagian akhir yang dituju, sedangkan fungsi menegaskan kegiatan atau aktifitas dalam rangka pencapaian tujuan. Bagi Wrenn, peran didefinisikan sebagai harapan-harapan dan perilaku yang dikaitkan dengan suatu posisi, sedangkan fungsi diartikan sebagai aktivitas yang ditunjukan bagi suatu peran.

Konselor dalam istilah Bahasa Inggris disebut counselor atau helper merupakan petugas khusus yang berkualifikasi dalam bidang konseling (counseling). Dalam konsep counseling for all, didalamnya terdapat kegiatan bimbingan (guidance), kata counselortidak dapat dipisahkan dari kata helping. Counselor menunjuk pada orangnya, sedangkan helping menunjuk pada profesinya atau bidang garapnya. Jika konselor adalah seseorang yang memiliki keahlian dalam bidang pelayanan konseling, ia sebagai tenaga profesional. $^{7}$

Ada banyak teori mengenai peran konselor, teori tersebut bermacammacam sesuai dengan asumsi tingkah laku serta tujuan yang akan dicapai oleh seorang konselor.

Ada beberapa pengertian peran konselor yang di buat para pakar yaitu:

Menurut Baruth dan Robinson Peran adalah apa yang diharapkan dari posisi yang dijalani seorang konselor dan persepsi dari orang lain terhadap posisi konselor tersebut. Sedangkan peran konselor menurut Baruth dan Robinson adalah peran yang inheren ada dan disandang oleh seseorang yang berfungsi sebagai konselor. ${ }^{8}$

Menurut Hornby Peran kerap diperlihatkan melalui perilaku individu di dterhadap penampilan, hak dan kewajiban yang memiliki hubungan dengan sebuah kedudukan. Sedangkan menurut Baruth dan Robinson, peran adalah sesuatu yang dibutuhkan atau diperlukan dari jabatan yang dimiliki

${ }^{7}$ Hartono and Boy Soedarmadji, Psikologi Konseling, 1st ed. (Jakarta: KENCANA, 2012). 50

${ }^{8}$ Namora Lumongga Lubis, Memahami Dasar-Dasar Konseling (Jakarta: KENCANA, 2011). 32 
seorang konselor dan persepsi dari orang lain terhadap posisi konselor tersebut. Misalkan, sikap kepedulian yang tinggi seorang konselor terhadap masalah klien. Dan sedangkan menurut Corey mengutarakan bahwa tidak ada satu pun jawaan sederhana yang mampu menerangkan bagaimana sebenarnya peran konselor yang layak. ${ }^{9}$

Menurut Rogers Adalah fasilitator dan reflektor. Disebut fasilitator karena konselor memfasilitasi atau mengakomodasi konseli mencapai pemahaman diri. Disebut reflektor karena konselor mengklarifikasi dan memantulkan kembali kepada klien perasaan dan sikap yang diekspresikannya terhadap konselor sebagai representasi orang lain. ${ }^{10}$

Dalam prosesm membantu seorang pecandu konselor adiksi memiliki kewajiban untuk melakukan Asesmen, Konseling dan Monitoring. Oleh karena itu sebagai konselor adiksi dituntut memiliki keterampilan berikut:

\section{Memiliki Pengetahun Tentang Narkotika}

Memiliki pengetahun dasar ketergantungan narkotika ialah bahwa ahli tersebut memahami pengetahuan umum tentang narkotikan, dapat menyebutkan dan menjelaskan golongan dari narkotikan, dapat menjelaskan cara-cara penggunaan narkotika, dapat mendefinikan ketergantungan fisiologis, dapat mendefinisikan adiksi, dapat menjalakan konsekuensi dari setidaknya enam jenis narkotika.

\section{Memiliki Keterampilan Asismen}

Memiliki kemampuan untuk melakukan asismen ketergantungan narkotika ialah melakukan satu proses penilaian (asesmen) pada penyalagunaan dan atau pecandu narkotika agar dapat diketahui derajat keparahan yang bersangkutan. Selain itu, keterampilan asesmen adalah pelaksanaan kegiatan semi struktur wawancara untuk dapat menentukan tata laksana terapi dan rancana tindak lanjut yang dapat disepakati oleh kedua belah pihak

\section{Memiliki Keterampilan Konseling}

Memiliki keterampilan konseling dalam ketergantungan narkotika maksudnya ialah ahli harus dapat melaksanakan kegiatan konseling dasar

\footnotetext{
${ }^{9}$ Mochamad Nursalim, Pengembangaan Profesi Bimbingan Dan Konseling (Jakarta: Erlangga, 2015). 78

${ }^{10}$ Robert L Gibson, Bimbingan Dan Konseling (Yogyakarta: Pustaka Pelajar, 2011). 215
} 
adiksi dimana proses konseling itu sendiri merupakan proses komunikasi dau arah antara terapis dengan penyalaguna dan atau pecandu narkotika dengan tujuan melakukan penggalian terhadap masalah-masalah baik yang menjadi penyebab dan atau akibat dari permasalahan adiksinya, serta memfasilitasi yang bersangkutan agar dapat menemukan jalan keluar dari permasalahan adiksi yang dialaminya.

\section{Memiliki Pengetahuan Penatalaksanaan Terapi Rehabilitasi}

Memiliki pengetahuan penalaksanaan terapi rehabilitasi berdasarkan jenis narkotika yang digunakan ialah ahli dapat menentukan baik secara individual dan atau bersama tim ahli perihal tatalaksana perawatan yang mendekati kebutuhan yang bersangkutan, apakah dalam tata laksana rawat inap atau rawat jalan, disertai perancangan kesepakatan terapi secara spesifik, terukur, dapat diakses, realistis, dan memiliki durasi waktu yang jelas berdasarkan jenis narkotika yang digunakan dan sebagainya.

\section{Penanganan Korban Penyalagunaan Napza Di Pusat Rehabilitasi Narkoba Galilea Palangkaraya}

Pada saat penelitian melaksanakan observasi di Yayasan pusat rehabilitasi narkoba galilea palangkaraya Kalimantan tengah. Peneliti melihat bahwah peran seorang konselor sangat mempengaruhi pemulihan dan pengembangan skil bagi pecandu narkoba sehingga penelitain ini di simpulkan dari hasi observasi penelitian.

Pembahasan hasil penelitian ini berdasarkan data dari laporan hasil penelitian, kajian teori mengenai peran konselor adiksi dalam menangani korban penyalagunaan napza di pusat yayasan rehabilitasi narkoba terhadap pemulihan dari pecandu narkoba yang telah di bahas sebelumnya serta telah ditambahkan dengan wawancara bersama konselor/staff yang bertugas di pusat rehabilitasi narkoba galilea. Pembahasan penelitian di bagi sesuai dengan tujuan penelitian. Tujuan penelitian dalam skripsi ini adalah melihat sejauh mana peran konselor dapat memulihkan korban penyalagunaan napza di pusat rehabilitasi narkoba galilea.

Pelayanan dan tindakan para konselor dan staff adalah pendorong utama bagi pemulihan pecandu narkoba. Konselor dan staff menjadi pendukung awal untuk penerimaan pecandu narkoba menjalani program trapi komunitas. Selain itu, staff bekerja sama dengan kedua orang tua pecandu narkoba dengan lebih baik maka pemulihan klien pecandu narkoba akan jauh lebih perkembangannya. Staff berusaha mendesai dan menjalankan program semenarik mungkin sehingga dapat mempengaruhi hati, pikiran dan jiwa 
peandu narkoba. Sedangkan orang tua harus memberikan kasih mesra dan perhatian kepada kliean pecandu narkoba agar klien itu merasa bahwa dia berharga dan diperhatikan.

\section{KESIMPULAN}

Kesimpulan berdasarkan analisis data yang secara representatife dalam penelitian tentang kondisi dan gambaran peran konselor dalam menangani korban penyalagunaan napza.

Pertama, Peran konselor sebagai fasilitator dalam menangani korban penyalagunaan napza di Yayasan Rehabilitasi Narkoba Galilea palangkaraya Kalimantan tengah. Konselor adalah orang yang memiliki keahlian dalam bidang pelayanan konseling, perannya menangani korban penyalagunaan napza, konselor melakukan beberapa hal yaitu: Asesmen, membantu pemulihan pecandu dan keluarganya, diadakan penilaian permasalah dengan cara mengumpulkan informasi, terutama melalui wawancara.

Konseling, merupan aktifitas yang dilakukan untuk memberikan berbagai alternative pemecahan masalah dan bersifat individual meskipun terkadang melibatkan lebih dari dua orang dan direncanakan untuk membantu korban memahami dan memperjelas masalah yang dihadapinya. Dan monitoring, pemantauan yang dapat dijelaskan sebagai kesadaran tentang apa yang ingin diketahui, monitoring akan memberikan informasi tentang status dan kecendrungan bahwa pengukuran evaluasi yang diselesaikan berulang dari waktu ke waktu.

Konselor memiliki tujuan memahami tingkah laku, motivasimotivasi dan perasaan pada konseli. Agar klien mendapatkan kelegaan, sedangkan, sedangkan tujuan jangka panjang adalah agar klien menjadi pribadi yang bermakna penuh.

Kedua, Efektifitas seorang konselor yang memiliki terampil, membangkitkan rasa percaya diri yang konselor bantu, menjangkau wawasan luas dan mendapatkan keterbukaan, mampu membangun suasana dengan baik. Konselor mampu berkumunikasi dengan hati-hati dan menghargai orang-orang yang dibantu dan berusaha tidak menyinggung orang yang di bantu, memiliki pengetahuan khusus dalambeberapa bidang keahlian yang mempunyai nilai bagi klien yang di bantu.

Berusaha memahami bukan menghakimi, berusaha membantu orang lain untuk merubah dari tingkahlaku merusak diri ke pola-pola tingkah laku yang secara pribadi lebih memuaskan. Dan konselor yang benar-benar efektif sangat terampil membantu orang-orang lain meliba diri sendiri, merespon secara tidak defense terhadap dan melakukan tugasnya melalui 
pendekatan behavior dengan keberhasilan.

\section{KEPUSTAKAAN}

Gani, Yarifuddin. "Therapeutic Community (TC) Pada Residen Penyalah Guna Narkoba Di Panti Social Marsudiputra Dharmapala Inderalaya Sumatera Selatan." Jurnal Konseling dan Pendidikan 1, no. 1 (2013): 54-57.

Gibson, Robert L. Bimbingan Dan Konseling. Yogyakarta: Pustaka Pelajar, 2011.

Hartono, and Boy Soedarmadji. Psikologi Konseling. 1st ed. Jakarta: KENCANA, 2012.

Lubis, Namora Lumongga. Memahami Dasar-Dasar Konseling. Jakarta: KENCANA, 2011.

Mappiare, Andi. Pengantar Konseling Dan Psikoterapi. Jakarta: Raja Grafindo Persada, 2006.

Martono, Lydia Harlina, and Satya Joewana. Menangkal Narkoba Dan Kekerasan: Belajar Hidup Bertanggung Jawab. Jakarta: Balai Pustaka, 2006.

Nursalim, Mochamad. Pengembangaan Profesi Bimbingan Dan Konseling. Jakarta: Erlangga, 2015.

Partodiharjo, Subagyo. Kenali NARKOBA Dan Musuhi Penyalahgunaannya. 1st ed. Jakarta: Erlangga, 2007.

Sasongko, Warso. Narkoba. Yogyakarta: Istana Media, 2017. Wahid, Abdul. Pelajar Indonesia Anti Narkoba Peran Pendidikan Kristen Dalam Penanggulangan Narkoba. Jakarta: Erlangga, 2016. 